\title{
Moveable Production Systems for Sustainable Development and Trade: Limitations, Opportunities and Barriers
}

\author{
Stephen Fox \\ VTT Technical Research Centre of Finland, FI-02044 VTT Espoo, Finland; stephen.fox@vtt.fi; \\ Tel.: +358-40-747-8801
}

Received: 19 August 2019; Accepted: 17 September 2019; Published: 20 September 2019

\begin{abstract}
It has been claimed that technological advances will make it possible to make anything anywhere and to do so sustainably. In particular, making anything anywhere would increase the diversity of locations and participants involved in production, with positive effects for sustainability. For example, increasing the diversity of locations can reduce the long-distance transportation of materials and goods, which can improve the ecological sustainability of production. At the same time, increasing the diversity of people included in manufacturing can contribute to the spread of manufacturing communities, which can improve the social sustainability of production. However, physical production continues to be dominated by the same countries that have dominated global manufacturing in recent decades. Meanwhile, trade imbalances between rich and poor countries are similar to those of the past. In this paper, limitations and opportunities are explained for moveable production systems to increase the diversity of locations and participants in global production and trade. In addition, potential geopolitical barriers to the deployment of moveable production systems are explained.
\end{abstract}

Keywords: global production networks; industrial development; industry 4.0.; leapfrog technology; moveable production systems; on-the-job training; product kits; sustainable development and trade; sustainable production

\section{Introduction}

In a 2006 edition of the scientific journal Nature, it was argued that technological advances would enable anything to be made anywhere [1]. Since then, expanding distributions of manufacturing to include more diverse locations and more diverse participants has grown as a topic of interest. For example, among governments, companies, communities, and individuals seeking to re-shore and re-distribute manufacturing [2,3]. In addition, as summarized in Figure 1, expanding geographic and demographic distributions of manufacturing has come to be associated with increasing ecological sustainability and social sustainability $[4,5]$. For example, increasing the diversity of locations included in manufacturing can reduce the long-distance transportation of materials and goods [6] and increasing the diversity of people included in manufacturing can contribute to the spread of manufacturing communities [7].

The importance of increasing diversity to improve production sustainability is recognized internationally. For example, China promotes wider geographical and social distribution of manufacturing through its "makerspaces for the people" policy. Like other countries, such as Britain [8] and India [9], China aims to increase the variety of manufacturing enterprises by including the creative potential of diverse individuals at diverse geographical locations $[10,11]$. Interest in increasing diversity in manufacturing distributions to improve ecological and social sustainability is encapsulated in the term "inclusive manufacturing" [12,13]. 


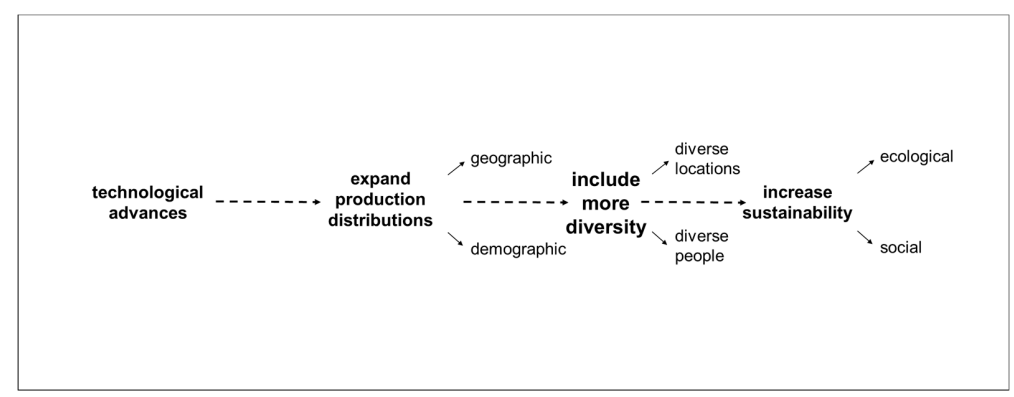

Figure 1. Inclusion of more diverse locations and people in production to increase its sustainability.

Technological advances do have some potential to expand the geographical distribution of manufacturing. For example, technological advances are leading to reductions in the number, size, weight and cost of machines needed in manufacturing [14], and different manufacturing processes being combined in hybrid machines [15]. Other technological advances have potential to expand the demographic distribution of manufacturing. For example, it has been argued that the expansion of Internet coverage and web-based platforms can enable a wider demographic distribution of manufacturing [16]. However, thirteen years after it was argued in Nature that technological advances would enable anything to be made anywhere [1], physical production is still dominated by the countries that dominated global manufacturing in 2006 [17]. Moreover, industrial manufacturing in many parts of the world, including Africa and India, has been reduced in what has been described as premature deindustrialization [18,19]. Furthermore, the do-it-yourself (DIY) maker movement, which, it was claimed, would provide a new industrial revolution [20], has contracted rather than expanded as its most well-known chain of maker workshops failed [21]. Hence, as summarized in Figure 2, patterns of trade in 2019 are similar to those of 2006.

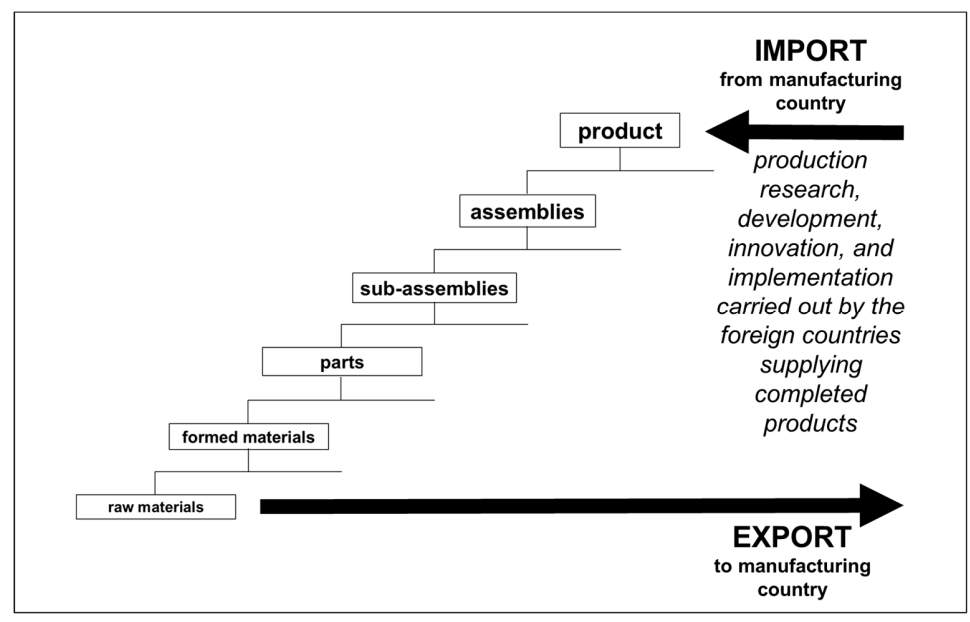

Figure 2. Exporting raw materials-importing completed goods.

In particular, many poor countries continue to export their raw material reserves, while the few nations that dominate global manufacturing export completed goods. This leaves poor countries with depleted raw materials reserves, stagnant low employment, and often, huge debts for the heavy infrastructure that has been constructed to expedite export of their raw materials. Meanwhile, the few countries that dominate global production continue to develop their expertise in research, development, innovation and implementation (RDII) of production [22-24], for example, through Industry 4.0 initiatives that involve cyber-physical systems, which require the integration of the Industrial Internet of Things, cloud computing, artificial intelligence, and other highly sophisticated technologies [25-27]. Some of these Industry 4.0 initiatives take into account the importance of ecological and social sustainability [28-32]. However, the sophistication of the technologies involved 
limit the potential for applications of Industry 4.0 independently of established organizations that have advanced technical capabilities.

Accordingly, this paper has two purposes. First, to explain the extent to which moveable production systems can increase the diversity of locations and participants in global production and trade. The focus is moveable production because it has potential to expand the distribution of production [33-35] and do so with more ecological and social sustainability than fixed factories [36,37]. Second, to explain geopolitical barriers to the deployment of moveable production systems, through triangulation of the following three theoretical perspectives: global production networks [38,39], rentier state theory [40,41], and theory of treadmill production and consumption [42,43].

The remainder of this paper comprises five further sections. In Section 2, the research methodology is described. In Section 3, an overview of moveable production systems is provided in terms of moveable factories, on-the-job training, and product kits. In Section 4, the extent to which moveable production systems can increase the diversity of locations and participants in global production and trade is explained. In Section 5, potential geopolitical barriers are analysed through theory triangulation. In Section 6, principal findings are stated, directions for further research are proposed, and implications for practice are explained.

\section{Methodology}

Throughout the research, multi-vocal literature reviews were carried out. These are literature reviews that include grey literature as well as formal scientific literature [44,45]. The majority of the literature referred to here is formal scientific literature. However, grey literature is also relevant because technological advances can involve fast moving trends that are reported contemporaneously in online media, but much more slowly in formal scientific literature. An example is the World Manufacturing Forum Report, Recommendations for The Future of Manufacturing [13]. Grey literature includes publicly available online information that may be produced by academia, businesses, communities, industries, governments, and/or NGOs, which is not necessarily peer reviewed and controlled by commercial publishers. The focus of search in grey literature was inclusive manufacturing, moveable production and enabling technologies.

Theory triangulation involves applying different theoretical perspectives in the examination of the phenomenon being researched. This is necessary because no single theory can have a monopoly on explanations [46]. Rather, each theory has its unique strengths and weaknesses that reflect the partial worldviews of any who develop a theory. Hence, the combination of multiple theories can yield a more complete picture of complex phenomena [47-49]. Theory triangulation can be applied to support the formulation of research propositions that have theoretical foundations and are not biased towards the views of one particular research group [50]. In particular, the application of different theoretical perspectives can reveal areas of theoretical agreement and disagreement. Both should be taken into account to avoid the formulation of partial research propositions [51]. In this research, the following three theoretical perspectives were applied: global production networks [38,39], Rentier State Theory [40,41], and Theory of Treadmill Production and Consumption [42,43]. Each of these three theoretical frameworks addresses production and trade from different perspectives. Accordingly, they facilitate the examination of moveable production systems from different perspectives.

\section{Moveable Production Systems}

In this section, moveable productions systems are described in terms of moveable factories, on-the-job training, and product kits.

\subsection{Moveable Factories}

Moveable factories enable necessary production resources to be brought to locations far from fixed factories: including to locations where there is no industrial infrastructure. Hence, although they are not necessarily hi-tech, moveable factories leapfrog over the need for industrial infrastructure [33-36]. 
The scope for moveable factories is increased by the range of manufacturing machines and power sources that are becoming small and light enough to fit into trucks, trailers, carry cases, etc. [14,15,52]. Moveable factories can expand the inclusivity of production by bringing necessary resources to more people in more places. In doing so, ecological sustainability can be improved by the construction of fewer factory buildings and less associated fixed infrastructure for power and transport. At the same time, social sustainability can be improved by expanding opportunities for social ownership through consequent reduction of capital investment costs [37,53].

Moveable factories can bring production to many locations and people that are underserved by extant production systems. Moveable factories can contribute to sustainable development through deployment at diverse locations, including farmyards, construction sites and conflict zones to produce many different types of components and goods [54-56]. Notably, moveable factories can be deployed for production processes that are typically associated with fixed factories. For example, moveable factories can produce bio-diesel in situ from biowaste product in rural areas [57,58]. In addition, moveable factories can be used in situ to transform any cellulosic materials into, for example, a bio-oil similar to crude oil, a synthesis gas similar to natural gas, or a bio-charcoal substance [59]. Moveable factories are versatile. For example, they can enable a wide variety of biowaste to be converted into fuel pellets and briquettes in situ [60,61]. Moreover, moveable factories can be used for agri-food processing $[62,63]$. The pros and cons of moveable factories compared to fixed factories can be assessed through conventional methodologies, such as break-even calculations and safety assessments [64-66]. As well as production, moveable factories can be deployed for in-situ recycling of a wide variety of materials ranging from building demolition rubble to electronic equipment waste $[67,68]$.

\subsection{On-the-Job Training}

Training for production work with moveable factories is not dependent upon medieval skill training practices, such as long apprenticeships, or 19th century practices, such as construction of fixed training centers in buildings. Rather, skills for production work with moveable factories can be instructed in a few days or hours of on-the-job training. For moveable factories used to process materials, on-the-job training is focused on instruction in machine operation. For moveable factories used to support the assembly of goods, instruction can also be carried out very quickly, provided uncertainty is engineered out of product kits that can be put together with moveable factories. This involves engineering production processes to be mistake-proof capable processes. This requires engineering production processes to conform to the production specification within upper and lower specification limits [69]. Upper and lower specification limits for production processes, which in some cases can be referred to as tolerances, are set in the context of material characteristics and product requirements. For example, timber is machined with saw blades that have to be strong enough by being thick enough to cut efficiently through dense natural wood that can have erratic grain patterns. The thicker the saw blade, the wider the distance between upper and lower specification limits. At the same time, upper and lower specification limits must be compatible with end-user product requirements. For example, timber sawn to plus or minus two millimeters $( \pm 2 \mathrm{~mm})$ is compatible with requirements for a partition wall but is not compatible with requirements for a dining table. Accordingly, sawn timber for use in furniture making will be processed subsequently in order to bring its dimensions within narrower specification limits. Upper and lower specification limits apply to completed goods as well as the materials that go into them. Consider, for example, shoes sizes. A women's shoe size of 35 (EU) should be $208 \mathrm{~mm}$. Moreover, it should be $14 \mathrm{~mm}$ less than a women's shoe size of 36 (EU). This example illustrates the importance of process capability to product users. In order to ensure conformance to upper and lower specification limits, shoes are made with the aid of physical molds called shoe lasts that have a similar shape to that of a human foot and the appropriate dimensions for a particular shoe size. The use of a wide variety of molds, dies, jigs, fixtures, and other tooling is well established throughout production processes to facilitate process capability [70] and can easily be applied with moveable production systems. Further refinement of production processes can be 
achieved by engineering to ensure that there is only one possible way of carrying out a task so that work can be carried out correctly the first time. In other words, the expenditure of mental and physical energy is focused on productive work: rather than energy being wasted in unproductive iterations of trial-and-error. When there is only one way to complete a task, then that task can be described as mistake-proof. This is a goal of many well-established techniques, including failure modes and effects analyses, and poka-yoke that seek to bring about high productivity mistake-proof production. Importantly, engineering design of mistake-proof capable processes enables the scaling up of production excellence to many different locations and many different participants [71-74].

\subsection{Product Kits}

An illustration of relevant differences between an imported completed product and a kit product comprising imported formed materials is shown in Figure 3.

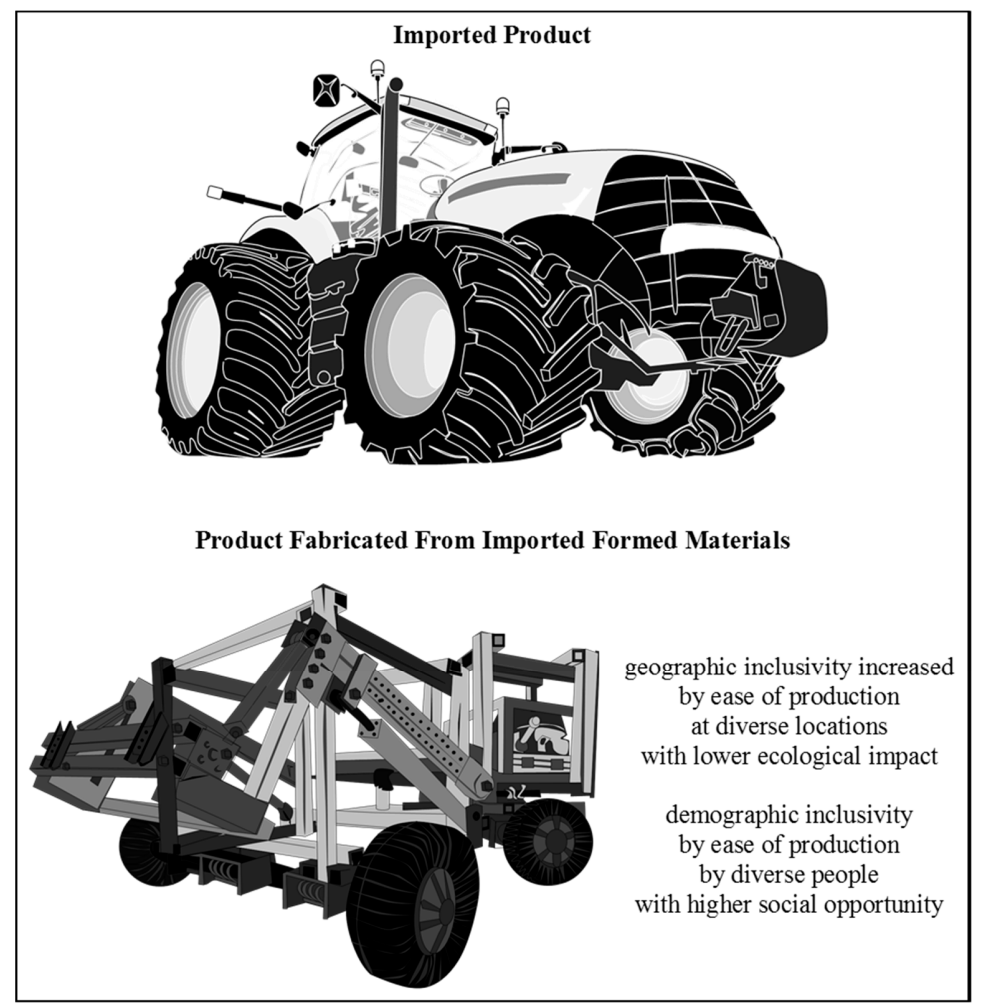

Figure 3. Imported product compared to product kit comprising imported formed materials.

The products shown in Figure 3 are tractors. The bottom tractor is a representation of open source tractor kits that are available with the Open Source Ecology movement, which enables sharing of the engineering design and its on-going development [75]. Importantly, it is a kit tractor that can be fabricated locally from commonly available formed materials such as metal box sections. Clearly, the kit tractor does not have the visual allure of the imported complete tractor. However, as summarized in Figure 4, from the point-of-view of sustainable development, the beauty of some products can be only skin-deep [76]. By contrast, the less aesthetically pleasing kit tractor has the characteristic of being able to facilitate a fundamental expansion of geographic and demographic inclusivity. The expansion is fundamental because, as summarized in Figure 4, open source product kits enable more production research, development, innovation and implementation (RDII) to be done inside the country. 


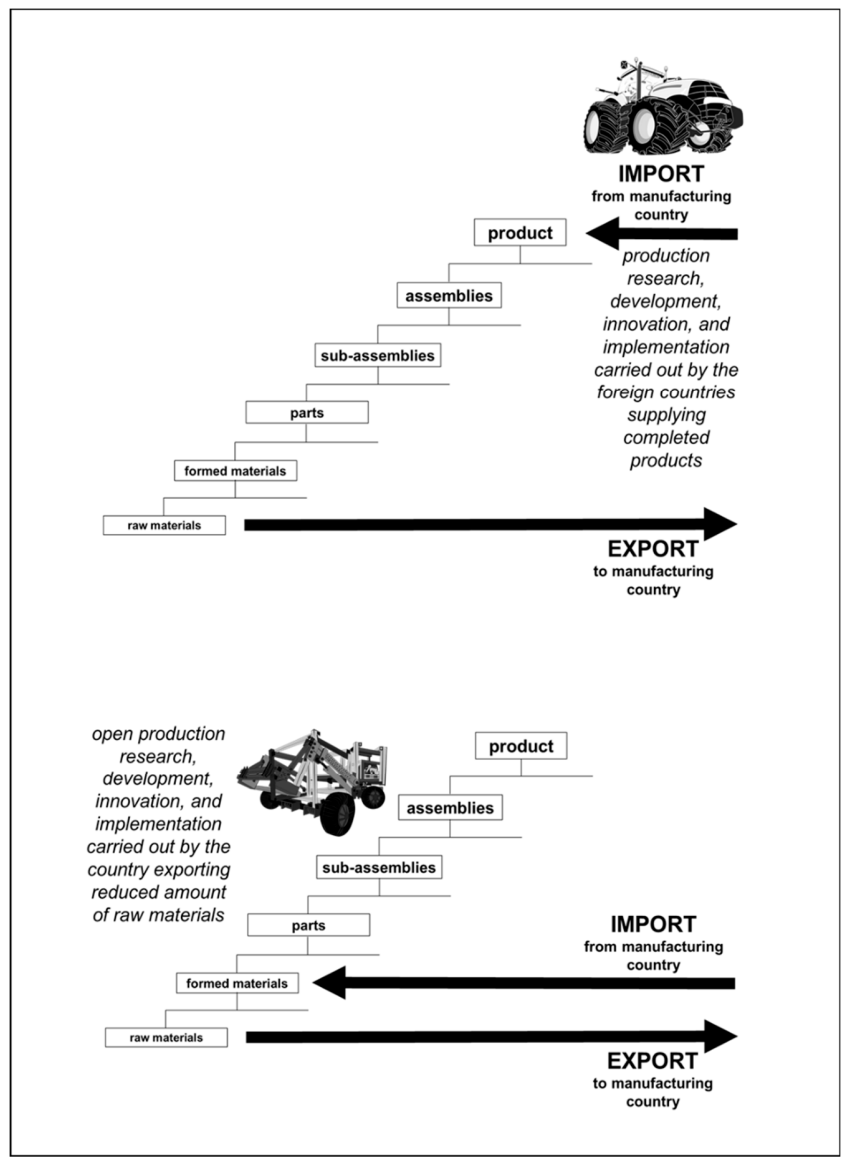

Figure 4. Reduced exports of raw materials and reduced imports of completed products.

Moreover, the country can export less of its raw materials because, rather than importing completed goods, it imports formed materials for making product kits inside the country, which can then be widely distributed for local assembly. Product kits that maximize the use of versatile commonly available materials have most potential for expanding the diversity of production locations. The most widespread around the world in 2019 are product kits for furniture [77]. However, components for products as large as passenger-carrying vehicles can be bundled together in semi knocked-down (SKD) kits or completely knocked-down (CKD) kits for assembly at diverse locations by diverse people [78]. People without relevant previous production experience can easily put product kits together [79]. This is because product kits radically reduce cognitive load and thus cut production times and defects, in assembly work [80,81]. Product kits also bring opportunities for expanding geographical and demographic inclusivity to diverse locations and people with advantages for ecological and social sustainability. In particular, geographic inclusivity can be increased by ease of production at diverse locations with lower ecological impact. This is because, for example, transportation of formed materials involves far less volume and weight than transportation of completed products. Demographic inclusivity can be increased by ease of production by diverse people who have increased social participation opportunities because of the low costs of product kits comprising commonly available formed materials.

\section{Potential of Moveable Production Systems}

In this section, the potential of moveable production systems is explained in terms of limitations and opportunities within the scope of those limitations. 


\subsection{Limitations}

Moveable production systems can be brought to a diverse range of locations through established technologies. For example, trucks already travel across rough ground in parts of the world without extensive road networks. Keeping them moving involves improvisation, including carrying cans of fuel and undertaking repairs far from garages. Speeds of travel can be slow, but nonetheless, destinations are reached. When moveable factories are purpose-built, they are equipped with their own means of power-generation. In addition, they carry repair equipment that is specific to the vehicle and to the production machines carried in the vehicle. The provision of production materials is addressed principally in two ways. Some moveable factories are deployed to process local materials, such as fruits and vegetables. In such applications, the moveable factories go to where the materials are located. Other moveable factories go to where goods are needed. In such applications, product kits need to be designed to include versatile materials, such as metal sheets and box sections, which can be transported flat-packed within kits [33-37,52-56].

Nonetheless, there are limitations to their potential scope of application. In particular, moveable production systems are not well-suited to the production of original one-of-a-kind goods. This is because exactly what materials, manufacturing equipment and manual skills will be needed in their production is not known from one product to the next. Hence, the equipping of moveable factories cannot be rationalized, product kits cannot be developed, and mistake-proof process capability cannot be engineered into production work in order to facilitate rapid on-the-job training [71-74]. Furthermore, moveable production systems are not well-suited to the production of the most complex products. For example, ocean-going cruise liners need to be produced at the vast specialized spaces of shipyards. Product complexity increases as numbers of part types, interconnection types, interface types, product technologies and product functions increase. The complexity of products is relative. For example, a family car is a more complex product than a bicycle. This is because a family car comprises more part types, more interconnections types, and more interface types than a bicycle. In addition, it involves more technologies in the provision of more functions [82,83]. Moreover, moveable production systems can do little to overcome the fundamental unsustainability of products that depend upon finite materials that are found in only a few places in the world, such as rare earths [84,85]. In addition, it is important to note that materials processing operations involved in the production of versatile materials, such as metal box sections, which are needed in some product kits, are not easily expanded to highly distributed production because they can require large spaces and energy-intense operations: for example at steel foundries. Hence, there is still some very long-distance transportation of formed materials involved, which can have negative ecological impacts [86,87]. Therefore, moveable production systems cannot sustainably enable making anything anywhere. Rather, they can enable a lot more things to be made in a lot more places a lot more sustainably. That is provided what is to be made is not too original, not too complex, and does comprise maximum locally sourced sustainable materials.

\subsection{Opportunities for Sustainable Production}

By 2019, the inclusivity of global production has been contracting rather than expanding. As summarized in Figure 5, extensive research by others has led to the identification of three major trends in manufacturing [88-91].

The first is that already industrialized high-income countries suffer falls in human factory jobs but can maintain factory output if there is major investment in factory innovation, such as autonomous robot workers. The second is that low-income countries, which have a head start in factory production, increase output and possibly human jobs if they have access to sufficient digital and physical infrastructure for them to be regional manufacturing hubs. The third is that low-income countries without a head start in factory jobs suffer a decline in both factory output and factory jobs. This is called premature industrialization because, as summarized in Figure 6, manufacturing is no longer available as "an escalator" for development, which lifts people out of poverty as they transition through producing increasing sophisticated goods [89,91]. 


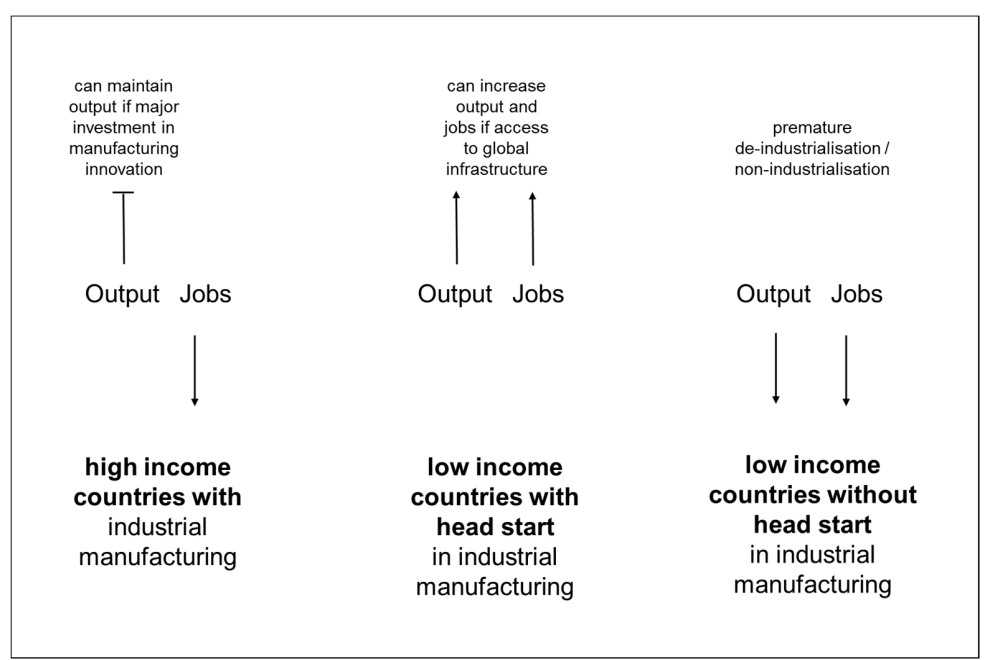

Figure 5. Trends in the distribution of global production.

Thus, rather than manufacture of anything anywhere, production is reducing in many parts of the world through delocalization [88-90,92-94]. Across these three trends is the capability of a few dominant countries to decide where production will be carried out [95-97]. Thus, in 2019, rather than the manufacture of anything anywhere, already dominant organizations in each production sector often decide where manufacturing will be carried out. They can decide where production will be located. Then, if they wish to do so, they can choose to automate production or move production somewhere else. This can leave the countries that host their production with little choice but to accept reduced human employment through automation [98-100].

By contrast, moveable production systems are not under the control of a few dominant organizations. Rather, their comparatively low capital investment costs can alleviate the decline of physical production work in low-income countries experiencing premature deindustrialization. More generally, moveable production systems are well-suited to enabling the distributed production of essential infrastructure at more diverse locations by more diverse people. In particular, location-specific sustainable infrastructure needs to be produced to meet the needs of the world's poor [101]. These needs encompass infrastructure for sustainable soil, water, energy, food [102-104]; sanitation, communication, transportation [105-107]; housing, healthcare, and education [108-110].

This is increasingly important because infrastructure provision for soil, water, energy, and food can reduce the ecological pressures that push people into rural exodus [111,112]. In addition, infrastructure provision for sanitation, communication, transportation can facilitate efficient local production and profitable regional commerce, which can reduce economic pressure to leave the countryside [113]. In addition, infrastructure provision for housing, healthcare, and education can contribute to balancing local population growth with local economic growth, and thus reduce social pressures that push people into moving to urban areas [114]. Reduction of ecological, economic, and social pressures can reduce the risk of violent conflicts that drive human tides of rural flight. In addition, the wide geographical distribution of comprehensive infrastructure provision can reduce justifications for massive centralized development projects, which can also lead to large-scale migration from rural areas $[115,116]$.

As well as agri-food processing and the manufacturing of many types of goods $[54,56]$, the production of essential infrastructure is within the scope of moveable production systems [55]. Thus, moveable production systems can have far-reaching practical implications arising from bringing the production of essential infrastructure to where essential infrastructure is needed. For example, the replacement of dirt floors with concrete floors in dwellings can reduce the risk of cholera with severe dehydration (CSD) by more than $60 \%$ [117]. The potential for such disease reduction by the simple action of improving flooring has been demonstrated in small field trials [118] and is the type of work that can easily be scaled up with moveable production systems to better enable sustainable development. 


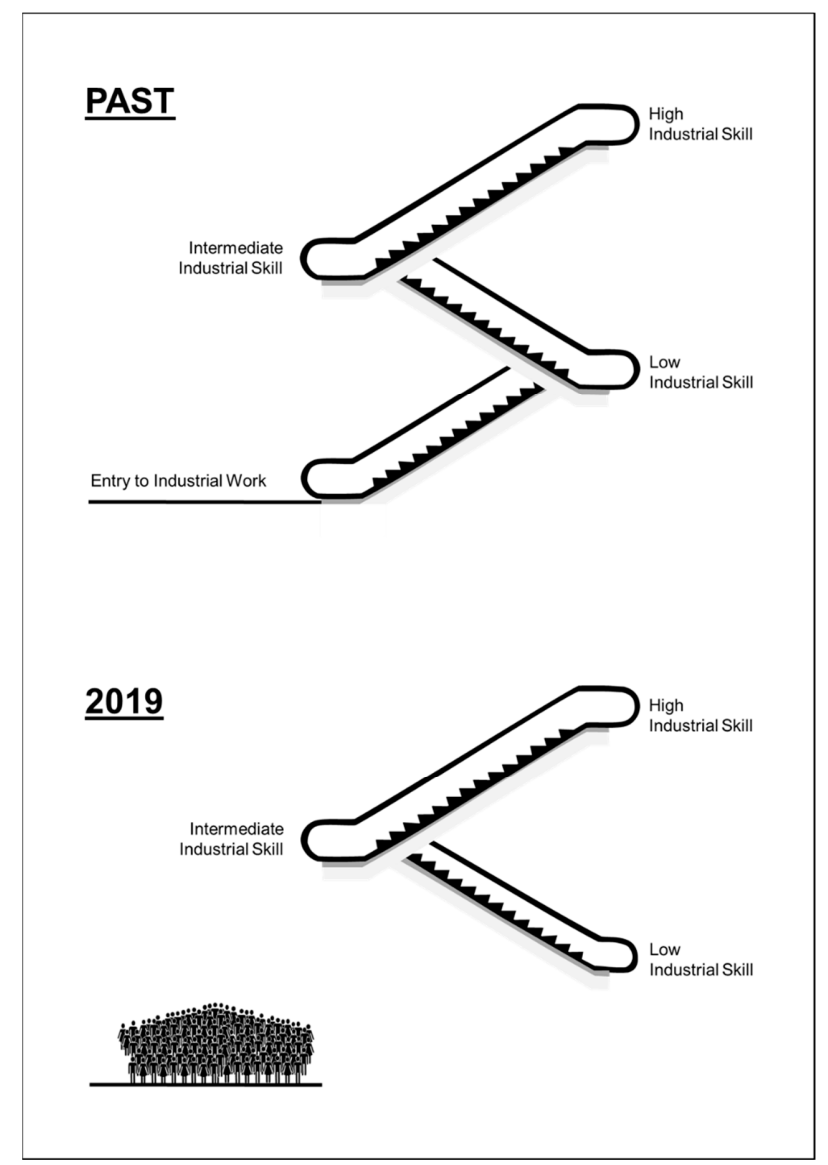

Figure 6. Reduced potential of fixed industrial manufacturing to lift people out of poverty.

\subsection{Opportunities for Sustainable Trade}

Adam Smith argued that there could be wealth for all countries if each country specializes in manufacturing and trading the goods that they can make with higher productivity than other countries. He called this the principle of absolute advantage, and it is has been further developed in subsequent theories of comparative advantage and competitive advantage [119-121].

Adam Smith was a professor of moral philosophy who believed increasing productivity to be a highly virtuous aim. Indeed, Adam Smith was a notable figure of the 18th century Enlightenment era [122]. This was a philosophical movement that emphasized the value of human beings [123,124]. Smith provided humanist ethical foundations for the Wealth of Nations in his earlier book, The Theory of Moral Sentiments. In this, he argued that people are motivated to behave in ways that any impartial spectator would approve of [125-127]. In doing so, he contributed to conceptualization of "the generalized other". This is the concept that a person has common expectations with other people about what are appropriate thoughts and actions within a particular society [122,128].

However, there are negative unintended consequences from the notion that there can be wealth for all countries if each country specializes in trading the goods that they can make with higher productivity than other countries [119-121]. Adam Smith began his book The Wealth of Nations by arguing that the greatest productivity improvements come from the division of labour [119]. Yet, division of labor reduces the work of individuals to tedious repetitive tasks, which may be regarded as virtuous by "the generalized other" who does not have to undertake the tedious repetitive tasks, but not by those who get repetitive strain injuries from actually doing the tasks [129]. Advances in automation offer ever-increasing opportunities to reduce the need for humans to undertake repetitive work, but this also reduces employment [88-93]. 
Furthermore, notions of equal wealth among nations being achieved by exporting based on superior productivity are dependent upon static equilibrium positions that do not hold in reality. Rather, exporting based on superior productivity tends to favour the countries that have a head start. For example, as summarized in Figure 2, many countries export raw materials or processed materials, while importing complete goods from countries that have a head start in manufacturing productivity [130-132]. This was the case in the time of Adam Smith [133] and is the case in 2019 [134].

As summarized in Figure 4, the deployment of open source product kits comprising standard versatile formed materials, in conjunction with moveable factories and on-the-job training, does not conform to notions of absolute advantage, comparative advantage, and competitive advantage that drive delocalization [119-121]. Rather, the emphasis is on reducing negative effects from other countries having a head start in the manufacture of complete goods. In particular, moveable production systems support the development of local expertise in production RDII in conjunction with international open source communities. Moreover, as capital investment costs are far lower for moveable production systems, there does not need to be fixation on comparative productivity between nations. Rather, open source community participants in different countries co-create knowledge about how to carry out production as efficiently as possible everywhere [75].

\section{Barriers for Moveable Production Systems}

In this section, an overview is provided of each of the three theoretical perspectives: global production networks, rentier state theory, and theory of treadmill production and consumption. Each of these different theoretical perspectives is related to moveable production systems, and research propositions are put forward.

\subsection{Global Production Networks (GPN)}

GPN are concerned with the international networks through which a product is made, distributed and consumed. GPN involve all participants in production, distribution and consumption, including social movements if they are participants. GPN encompasses temporary and persistent networks, which may span the borders of neighbors or the entire world. The consideration of embeddedness is important in GPN as many sources of materials and means of production are fixed at specific locations. Furthermore, GPN considers embeddedness to include the network embeddedness of connections between participants regardless of geographical positions. In addition, GPN are considered to be embedded in participants' different socio-economic priorities, which can lead to GPN involving some conflict, as well as cooperation, over their arrangement and operation. Conflict and cooperation can involve vertical and horizontal network relations. The outcomes of GPN interactions are determined jointly by vertical network relations between suppliers and buyers, together with horizontal relations between different bodies concerned with labor and the environment $[38,39]$.

In terms of GNP, moveable production systems increase the relative significance of social movements such as Open Source Ecology [75]. In addition, moveable production systems increase the prevalence of temporary networks in some phases of production. For example, assembly operations involve temporary interactions at the locations where moveable factories are sited for a short time. However, other phases of production depend on persistent relationships: for example, with suppliers of versatile materials. Thus, geographical embeddedness is less than in other GPN but network embeddedness is equally important, with social movements providing vital horizontal support for moveable production systems. Conflict can be expected in vertical network relations in GPN because, as summarized in Figure 4, outbound supply of natural resources is reduced and inbound buying of completed goods is reduced. Conflict can take the form of dominant manufacturers crushing emerging competition through aggressive pricing strategies such as dumping. This happens when manufacturers export a product to another country at a price below the normal price with an injuring effect, such as radically reducing the sales of emerging competitors. For example, a dominant foreign manufacturer pushed out of business the maker enterprise of the maker movement advocate who claimed that it 
would bring a new industrial revolution [20,135]. Hence, it is important to recognize that any use of moveable production systems to manufacture goods equivalent to those of dominant manufacturers is likely to encounter aggressive competitive strategies. However, as illustrated in Figure 3, open source kits can provide products that are fit-for-purpose, but which are not in direct competition with the offerings of dominant manufacturers. Moreover, moveable product systems can be deployed in a wide range of situations where the offerings of established manufacturers are of limited usefulness [54-68]. Thus, moveable production systems can go beyond previous import-substitution industrialization and previous export-led industrialization that have failed to meet development needs in many parts of the world [22-24,136].

Research Proposition 1: Foreign organizations that need to export high quantities of completed goods can act against the scaling up of moveable production systems in other countries if they are used for manufacturing equivalent goods.

\subsection{Rentier StateTheory}

Economic rent involves unearned payments for sale of a factor of production, including payments to government for sale of natural resources. Within rentier state theory, it is posited that governments are more likely to be responsive to their citizens if the government depends for its income on its citizens paying personal taxation. By contrast, governments of countries that receive large payments (i.e., economic rent) from foreign organizations for its natural resources are less likely to be responsive to the needs of its citizens. This trend is reinforced by extraction and processing of natural resources providing little local employment that could lead to citizens making taxation payments. Meanwhile, payment by foreign organizations directly to government provides its ministers with little incentive to seek to develop a productive sector that could generate large-scale employment. Then, as governments become more experienced in negotiating with foreign organizations, they become more skilled in getting deals for themselves and need to generate local employment to generate tax incomes from citizens decreases [40,41,137,138].

This theory is particularly relevant to the introduction and scaling up of moveable production systems in countries that have natural materials available for export in return for large payments from foreign organizations. In such countries, it cannot be expected that government will definitely demonstrate commitment to stimulating and supporting the development of a productive sector: even when moveable production systems reduce the time and cost involved in doing so. In other words, the advantages of moveable production systems cannot be assumed to override the so-called, resource curse. That is the long-observed paradox that some countries with an abundance of natural resources have worse development outcomes than countries with fewer natural resources [139,140]. Importantly, the export of natural resources can bring massive incomes for government officials whether or not there is national socio-economic development. Indeed, some research indicates that bad government and associated conflicts increase dependence on the export of natural resources. The mobility of moveable production systems makes them suitable for setting up production operations amidst conflict. Nonetheless, if everyone with entrepreneurial ambition has had to flee from the region of conflict and there is no government support for productive enterprise, it cannot be assumed that moveable production systems will be introduced [141]. Rather, governments can argue that the only option for achieving economic growth is to export raw materials: even though this can facilitate negative net resource transfers and bring little, if any, growth in employment [142].

Research Proposition 2: Government officials who can receive incentives from foreign organizations for facilitating raw materials exports can act against scaling up of moveable production systems in their own countries. 


\subsection{Theory of Treadmill Production and Consumption}

As illustrated in Figure 7, this theory posits that injustice and unsustainability in the global economy arises from alliance between industrial capital that has pressure to expand continually due to its large fixed costs, for example in fixed factories, large-scale organized labor, and government [42,43].

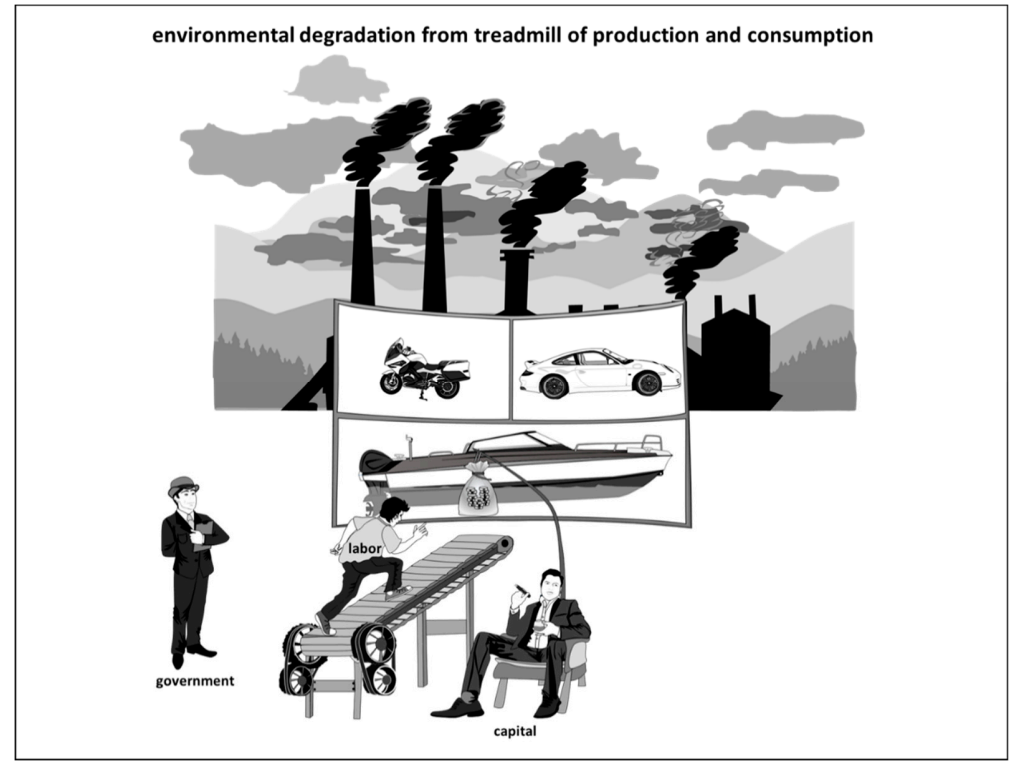

Figure 7. Treadmill of production and consumption metaphor.

Within this theory, it is argued that the desire for economic expansion provides common political ground for cross-sector alliances of capital, labor, and government to postpone potential disagreements by all agreeing on economic growth. As illustrated in Figure 7, it is argued, through the metaphor of a treadmill, that this agreement is promoted by industrial capital, which promises large-scale work employment in the large-scale production of goods for throwaway consumption. Furthermore, it is argued that capital always wants the treadmill to accelerate in order to cover its debts and increase its profits. This acceleration leads to ever increasing environmental degradation as increasing amounts of materials are extracted, processed, and transported in the production of goods for consumption. However, it is argued that the power of capital to continually push for acceleration of the treadmill to increase its profits can be reduced if labor and government can be educated about the finite potential for environmental degradation [42,43].

Consideration of this theory highlights that having a government being dependent on tax payments from its citizens, rather than payments from foreign organizations, does not necessarily lead to favorable outcomes for society. Moreover, this theory highlights that even if GPN can be established with social movements, such as Open Source Ecology, and even if government is committed to development of a productive sector, it cannot be assumed that there will not be unsustainability. Rather, agglomeration can be greenwashed through measures that reduce ecological impact per unit of production, but within the context of agglomeration that depends upon the continual expansion of the volume of goods that are produced $[143,144]$. Furthermore, consideration of this theory highlights the tendency towards agglomeration in production systems where capital and labor come to be concentrated in a few large companies at a few locations with the support of government. This tendency can lead to so-called location tournaments in which different countries' and regions' governments compete with each other to attract foreign organizations to build their fixed factories where they can provide large numbers of their citizens with taxable incomes [145].

It is important to note that the incentives offered can exceed subsequent taxation incomes, but nonetheless, government can claim to be taking action to generate large numbers of new jobs for voters. Furthermore, as a large number of new jobs can be quantified in advance, winning a location 
tournament can be a more attractive political option than supporting widely distributed initiatives such as moveable production systems [146,147].

Research Proposition 3: Industrial capital can act against the widespread deployment of moveable production systems if their deployment undermines production agglomeration.

\subsection{Addressing Barriers}

Findings from theory triangulation indicate that moveable production systems having the capability to expand locations and people involved in production work is not a sufficient condition to bring about more sustainable development and trade. Rather, powerful incumbents in global production and trade can continue to drive agglomeration and associated delocalization. Accordingly, it is doubtful whether the potential of moveable production systems can be realized solely through bottom-up initiatives. Rather, top-down initiatives may also be required to overcome the potential barriers revealed through theory triangulation. In particular, cross-sector alliances can counterbalance extant cross-sector alliances of capital, labor and government $[148,149]$. As well as enterprises that develop and operate moveable production systems, cross-sector alliances can include government and non-governmental organizations focused on sustainable development and trade. However, such cross-sector alliances should focus their efforts on meeting unmet demand for local sustainable production rather than go into direct competition with extant cross-sector alliances $[150,151]$. Thus, moveable production systems can be deployed to better enable sustainable development and trade by addressing gaps in supply from agglomerated, delocalized, production.

\section{Conclusions}

In this concluding section, principal findings are stated, directions for future research are proposed, and implications for practice are discussed.

\subsection{Principal Findings}

Moveable production systems, which comprise moveable factories, on-the-job training, and product kits, do not necessarily have to involve the very latest technological advances. Rather, moveable factories can be mounted on second-hand trucks. Furthermore, product kits can comprise versatile materials that have been available for decades such as standard metal sections. In addition, rapid on-the-job training can be facilitated by the application of very well-established techniques in the engineering design of mistake-proof production.

In particular, the findings indicate that moveable production systems have the potential to expand diversity in global production and trade: especially where there is a need for essential goods and infrastructure that can be engineered into kits comprising common versatile materials. There is great need for such product kits in low incomes countries, which, as summarized in Figure 5, are experiencing low manufacturing output and employment due to premature deindustrialization. Thus, moveable production systems can bring production work where it is needed most by enabling local manufacture of essential goods and essential infrastructure where they are needed most. As summarized in Figure 4, moveable production systems can also expand the geographic and demographic diversity of trade as well as production. However, theory triangulation indicates that foreign organizations, government officials, and industrial capital can have powerful motivations to act against the scaling up of moveable production systems. In particular, theory triangulation reveals potential barriers in deploying moveable production systems. Firstly, conflict can be anticipated in vertical network relationships in GPN because, as summarized in Figure 4, outbound supply of natural resources and inbound buying of completed goods can both be reduced. Second, despite the low cost and high mobility of moveable production systems, it cannot be assumed that government officials of countries most in need of productive sector development will resist incentives from foreign organizations to focus instead on selling of high volumes of natural resources. Third, even if government is committed to development of a productive sector, it cannot be assumed that there will not be continuing agglomeration and delocalization 
in production. Accordingly, there is a need to form cross-sector alliances in order to support the introduction of moveable production systems.

\subsection{Directions for Future Research}

One direction for future research is to investigate the potential for improving the sustainability of production with moveable production systems that are not reliant on sophisticated technologies, such as Industrial Internet of Things, cloud computing, artificial intelligence, which are seen as being as being important within established conceptualizations of Industry 4.0 [25-32].

Rather, the comparative simplicity of moveable production systems, together with their high mobility, facilitates their introduction in fragile regions where there is urgent need for local employment, essential goods and essential infrastructure. Accordingly, another direction for future research is investigating to what extent, if any, potential motivations of foreign organizations, government officials, and industrial capital can act against the introduction of moveable production systems in fragile regions. More broadly, another direction for future research is to investigate to what extent, if any, moveable production systems can contribute to what is described as inclusive manufacturing in countries that have different levels of existing economic development. Inclusive manufacturing has been stated to be a major theme in the annual report of the World Manufacturing Forum, within which it is argued to have the following three dimensions [13]: adoption of basic to cutting-edge technologies; employment of all categories of people; enable a sustainable economic growth. Again, an important topic for research is to investigate the extent to which potential vested interests can act against the scaling up of moveable production systems irrespective of their potential to contribute to goals of inclusive manufacturing.

\subsection{Implications for Practice}

To date, sustainable development practice has been focused on village-scale interventions or large-scale capital projects. A shortcoming of both these scales of interventions is that they are not engineered to be scaled up to address gaps between the demand for and supply of essential goods and infrastructure in underserved countries. Moreover, it is not anticipated that current approaches will provide sufficient employment to lift mass of people out of poverty [152]. By contrast, moveable production systems are scalable because, as explained in Section 3 and summarized in Figure 8, they can be engineered for scaling up through application of techniques that ensure consistent capability of processes [69-74]. Furthermore, movable production systems can go to where there are gaps between demand and supply. In doing so, they can facilitate local employment and prosumption in which people produce what they consume.

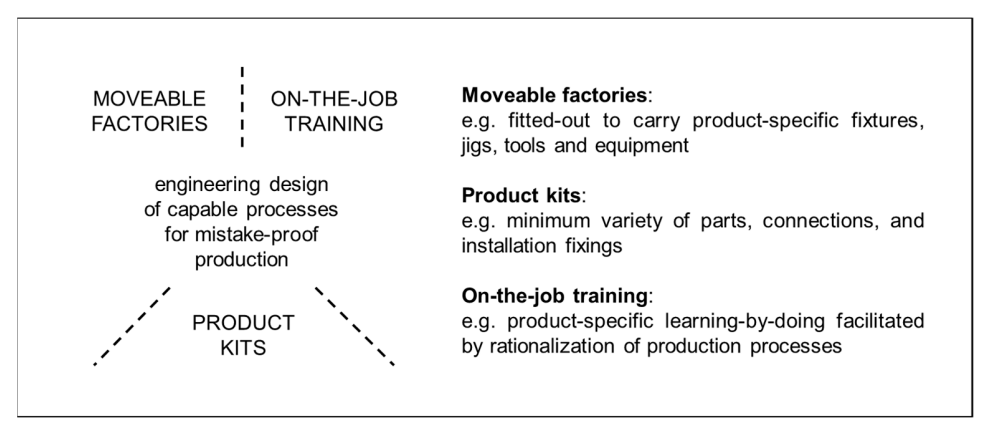

Figure 8. Engineering moveable production systems to scale up sustainable development and trade.

As moveable production systems do not incur the cost of constructing factory buildings, their capital investment costs are comparatively low. However, their capital costs are beyond the scope of micro-finance for individuals. Rather, they are better suited to ownership and operation by social enterprises or by small companies. In addition,, there are opportunities for owning to lease to others. 
For example, moveable factories are suitable for short-term leasing to different lessees in the same way as other types of capital equipment are leased by plant hire companies. Thus, the financing of moveable production systems, which can improve the ecological and social sustainability of production, are well-suited cross-sector initiatives for funding entrepreneurship to support the three pillars of sustainable development: economy, ecology and society [153].

Funding: This research received no external funding.

Acknowledgments: The author thanks Päivi Vahala for realization of graphics in Figures 3,6 and 7. Also, the author thanks Minna Lanz and Esko Niemi for critical discussion of terminology in the second paragraph of Section 4.1.

Conflicts of Interest: The author declares no conflict of interest.

\section{References}

1. Mandavilli, A. Make anything, anywhere. Nature 2006, 442, 862-864. [CrossRef] [PubMed]

2. Jreissat, M.; Isaev, S.; Moreno, M.; Makatsoris, C. Consumer driven new product development in future re-distributed models of sustainable production and consumption. Procedia CIRP 2017, 63, 698-703. [CrossRef]

3. Stentoft, J.; Mikkelsen, O.S.; Jensen, J.K.; Rajkumar, C. Performance outcomes of offshoring, backshoring and staying at home manufacturing. Int. J. Prod. Econ. 2018, 199, 199-208. [CrossRef]

4. Mani, V.; Gunasekaran, A.; Delgado, C. Enhancing supply chain performance through supplier social sustainability: An emerging economy perspective. Int. J. Prod. Econ. 2018, 195, 259-272. [CrossRef]

5. Rauch, E.; Dallinger, M.; Dallasega, P.; Matt, D.T. Sustainability in manufacturing through distributed manufacturing systems (DMS). Procedia CIRP 2015, 29, 544-549. [CrossRef]

6. Wolf-Powers, L.; Doussard, M.; Schrock, G.; Heying, C.; Eisenburger, M.; Marotta, S. The Maker Movement and urban economic development. J. Am. Plann. Assoc. 2017, 83, 365-376. [CrossRef]

7. O'Sullivan, E. Excellence in the maker movement. J. Peer Prod. 2018, 3, 46-50.

8. Moreno, M.; Charnley, F. Can re-distributed manufacturing and digital intelligence enable a regenerative economy? An integrative literature review. In Sustainable Design and Manufacturing; Springer: Cham, Switzerland, 2016; pp. 563-575.

9. Mudambi, R.; Saranga, H.; Schotter, A. Mastering the make-in-India challenge. MIT Sloan Manag. Rev. 2017, $58,59-66$.

10. Lindtner, S. Hacking with Chinese characteristics: The promises of the maker movement against China's manufacturing culture. Sci. Technol. Hum. Values 2015, 40, 854-879. [CrossRef]

11. Marshall, J.; Rossi, C. Making with China. Digit. Cult. Soc. 2017, 3, 127-138. [CrossRef]

12. NIAS. Inclusive Manufacturing Forum Report 2018; National Institute of Advanced Studies: Bangaluru, India, 2018.

13. WMF. World Manufacturing Forum Report, Recommendations for The Future of Manufacturing 2018. Available online: https://docs.wixstatic.com/ugd/03d390_b6ae0b7ab0da48ca90903b3817be00e6.pdf (accessed on 7 September 2019).

14. Brecher, C.; Utsch, P.; Klar, R.; Wenzel, C. Compact design for high precision machine tools. Int. J. Mach. Tools Manuf. 2010, 50, 328-334. [CrossRef]

15. Flynn, J.M.; Shokrani, A.; Newman, S.T.; Dhokia, V. Hybrid additive and subtractive machine tools: Research and industrial developments. Int. J. Mach. Tools Manuf. 2016, 101, 79-101. [CrossRef]

16. Jiang, P.; Leng, J.; Ding, K.; Gu, P.; Koren, Y. Social manufacturing as a sustainable paradigm for mass individualization. J. Eng. Manuf. 2016, 230, 1961-1968. [CrossRef]

17. Li, L. China's manufacturing locus in 2025: With a comparison of "Made-in-China 2025" and "Industry 4.0". Technol. Forecast. Soc. 2018, 135, 66-74. [CrossRef]

18. Grabowski, R. Premature deindustrialization and inequality. Int. J. Soc. Econ. 2017, 44, 154-168. [CrossRef]

19. Rodrik, D. Premature deindustrialization. J. Econ. Growth 2016, 21, 1-33. [CrossRef]

20. Anderson, C. Makers: The New Industrial Revolution; Random House Inc.: New York, NY, USA, 2012.

21. Malone, E. Mourning the loss of TechShop. Make Magazine, 16 November 2017. 
22. Baldwin, R. Trade and industrialization after globalization's second unbundling: How building and joining a supply chain are different and why it matters. In Globalization in an Age of Crisis: Multilateral Economic Cooperation in the Twenty-First Century; Feenstra, R.C., Taylor, A.M., Eds.; University of Chicago Press: Chicago, IL, USA, 2013; pp. 165-212.

23. Langan, M. Neo-Colonialism and foreign corporations in Africa. In Neo-Colonialism and the Poverty of 'Development' in Africa. Contemporary African Political Economy; Palgrave Macmillan: Cham, Switzerland, 2018; pp. 33-60.

24. Sanusi, L. Africa must get real about Chinese ties. Financial Times, 11 March 2013.

25. Wan, J.; Xia, M. Cloud-assisted cyber-physical systems for the implementation of Industry 4.0. Mob. Netw. Applic. 2017, 22, 1157-1158. [CrossRef]

26. Wollschlaeger, M.; Sauter, T.; Jasperneite, J. The future of industrial communication: Automation networks in the era of the Internet of Things and Industry 4.0. IEEE Ind. Electron. Mag. 2017, 11, 17-27. [CrossRef]

27. Lee, J.; Davari, H.; Singh, J.; Pandhare, V. Industrial Artificial Intelligence for Industry 4.0-based manufacturing systems. Manuf. Lett. 2018, 18, 20-23. [CrossRef]

28. Stock, T.; Seliger, G. Opportunities of sustainable manufacturing in industry 4.0. Procedia CIRP 2016, 40, 536-541. [CrossRef]

29. Stock, T.; Obenaus, M.; Kunz, S.; Kohl, H. Industry 4.0 as enabler for a sustainable development: A qualitative assessment of its ecological and social potential. Process. Saf. Environ. Prot. 2018, 118, 254-267. [CrossRef]

30. Müller, J.M.; Voigt, K.I. Sustainable industrial value creation in SMEs: A comparison between Industry 4.0 and made in China 2025. Int. J. Precis. Eng. Manuf. Green Technol. 2018, 5, 659-670. [CrossRef]

31. Birkel, H.S.; Veile, J.W.; Müller, J.M.; Hartmann, E.; Voigt, K.-I. Development of a Risk Framework for Industry 4.0 in the Context of Sustainability for Established Manufacturers. Sustainability 2019, 11, 384. [CrossRef]

32. Müller, J.M.; Kiel, D.; Voigt, K.-I. What Drives the Implementation of Industry 4.0? The Role of Opportunities and Challenges in the Context of Sustainability. Sustainability 2018, 10, 247.

33. Adamietz, R.; Giesen, T.; Mayer, P.; Johnson, A.; Bibb, R.; Seifarth, C. Reconfigurable and transportable container-integrated production system. Robot. Comp. Integr. Manuf. 2018, 53, 1-20. [CrossRef]

34. Behzad, A.; Pirayesh, M.; Ranjbar, M. Routing and Production Scheduling for a Mobile Factory. Int. J. Ind. Eng. Prod. Res. 2017, 28, 299-308.

35. Benama, Y.; Thecle, A.L.I.X.; Perry, N. Framework definition for the design of a mobile manufacturing system. In Advances on Mechanics, Design Engineering and Manufacturing; Springer: Cham, Switzerland, 2017; pp. 111-118.

36. Fox, S. Moveable factories: How to enable sustainable widespread manufacturing by local people in regions without manufacturing skills and infrastructure. Technol. Soc. 2015, 42, 49-60. [CrossRef]

37. Fox, S.; Mubarak, Y.M. Moveable social manufacturing: Making for shared peace and prosperity in fragile regions. Technol. Soc. 2017, 51, 1-7. [CrossRef]

38. Coe, N.M.; Hess, M.; Yeung, H.W.-C.; Dicken, P.; Henderson, J. Globalizing regional development: A global production networks perspective. Trans. Inst. Br. Geogr. 2004, 29, 468-484. [CrossRef]

39. Lund-Thomsen, P.; Lindgreen, A. Is there a sweet spot in ethical trade? A critical appraisal of the potential for aligning buyer, supplier and worker interests in global production networks. Geoforum 2018, 90, 84-90. [CrossRef]

40. Omeje, K.D. (Ed.) Extractive Economies and Conflicts in the Global South: Multi-Regional Perspectives on Rentier Politics; Ashgate Publishing, Ltd.: Farnham, UK, 2008.

41. Yates, D.A. The Rentier State in Africa; Africa World Press: Trenton, NJ, USA, 1996.

42. Gould, K.A.; Pellow, D.N.; Schnaiberg, A. Treadmill of Production: Injustice and Unsustainability in the Global Economy; Routledge: Abingdon, UK, 2015.

43. Schnaiberg, A. The Environment: From Surplus to Scarcity; Oxford University Press: New York, NY, USA, 1980.

44. Bogdanski, S.; Chang, B.C. Collecting grey literature: An annotated bibliography, with examples from the sciences and technology. Sci. Tech. Libr. 2005, 25, 35-70.

45. Patton, M.Q. Towards utility in reviews of multivocal literatures. Rev. Educ. Res. 1991, 61, $287-292$.

46. Fawcett, J.; Downs, F.S. The Relationship of Theory and Research; Appleton-Century-Crofts: Norwalk, CT, USA, 1986.

47. Bhaskar, R. Scientific Realism and Human Emancipation; Verso: London, UK, 1986.

48. Elder-Vass, D. The Reality of Social Construction; Cambridge University Press: Cambridge, UK, 2012. 
49. Modell, S. Theoretical triangulation and pluralism in accounting research: A critical realist critique. Acc. Audit. Account. J. 2015, 28, 1138-1150. [CrossRef]

50. Denzin, N.K. Sociological Methods: A Sourcebook; Routledge: New York, NY, USA, 2017.

51. Tibben, W.J. Theory building for ICT4D: Systemizing case study research using theory triangulation. Inform. Technol. Dev. 2015, 21, 628-652. [CrossRef]

52. Fox, S.; Richardson, M. Moveable factories for leapfrog manufacturing in an industrial economy. Technologies 2017, 5, 13. [CrossRef]

53. Fox, S. Third Wave Do-It-Yourself (DIY): Potential for prosumption, innovation, and entrepreneurship by local populations in regions without industrial manufacturing infrastructure. Technol. Soc. 2014, 39, 18-30. [CrossRef]

54. O’Bryan, C.A.; Crandall, P.G.; Davis, M.L.; Kostadini, G.; Gibson, K.E.; Alali, W.Q.; Marcy, J.A. Mobile poultry processing units: A safe and cost-effective poultry processing option for the small-scale farmer in the United States. World Poult. Sci. J. 2014, 70, 787-802. [CrossRef]

55. Rauch, E.; Matt, D.T.; Dallasega, P. Mobile On-site Factories—Scalable and distributed manufacturing systems for the construction industry. In Proceedings of the IEEE International Conference on Industrial Engineering and Operations Management (IEOM), Dubai, UAE, 3-5 March 2015; pp. 1-10.

56. Richman, T. Mobile Parts Hospital-The Agile Manufacturing Cell Provides Critical Parts to Soldiers in Battle. Available online: https://apps.dtic.mil/dtic/tr/fulltext/u2/a459209.pdf (accessed on 7 September 2019).

57. Kate, J.; Teunter, R.; Kusumastuti, R.D.; van Donk, D.P. Bio-diesel production using mobile processing units: A case in Indonesia. Agric. Syst. 2017, 152, 121-130. [CrossRef]

58. Oliveira, L.S.; Brasil, A.N.; Nunes, D.L. Design and Operation of a Mobile Biodiesel Production Unit. In Proceedings of the 2009 International Conference on Chemical, Biological and Environmental Engineering, Singapore, 9-11 October 2009; pp. 29-32.

59. Palma, M.A.; Richardson, J.W.; Roberson, B.E.; Ribera, L.A.; Outlaw, J.L.; Munster, C. Economic feasibility of a mobile fast pyrolysis system for sustainable bio-crude oil production. Int. Food Agribus. Manag. Rev. 2011, 14, 1-16.

60. Martínez, M.G.; Dupont, C.; da Silva Perez, D.; Míguez-Rodríguez, L.; Grateau, M.; Thiéry, S.; Gourdon, C. Assessing the suitability of recovering shrub biowaste involved in wildland fires in the South of Europe through torrefaction mobile units. J. Environ. Manag. 2019, 236, 551-560. [CrossRef]

61. Severy, M.A.; Chamberlin, C.E.; Eggink, A.J.; Jacobson, A.E. Demonstration of a pilot-scale plant for biomass torrefaction and briquetting. Appl. Eng. Agric. 2018, 34, 85-98. [CrossRef]

62. Eriksen, M.S.; Rødbotten, R.; Grøndahl, A.M.; Friestad, M.; Andersen, I.L.; Mejdell, C.M. Mobile abattoir versus conventional slaughterhouse-Impact on stress parameters and meat quality characteristics in Norwegian lambs. Appl. Anim. Behav. Sci. 2013, 149, 21-29. [CrossRef]

63. Mancinelli, A.C.; Dal Bosco, A.; Mattioli, S.; Ranucci, D.; Castellini, C. Mobile poultry processing unit as a resource for small poultry farms: Planning and economic efficiency, animal welfare, meat quality and sanitary implications. Animals 2018, 8, 229. [CrossRef] [PubMed]

64. Kweon, H.K.; Rhee, H.; Lee, J.W.; Choi, S. Efficacy and profitability of a mobile grinder system for biomass production in Korea. For. Sci. Technol. 2016, 12, 219-223. [CrossRef]

65. Angioloni, S.; Kostandini, G.; Alali, W.Q.; O’Bryan, C.A. Economic feasibility of mobile processing units for small-scale pasture poultry farmers. Renew. Agric. Food Syst. 2016, 31, 387-401. [CrossRef]

66. Trimble, L.M.; Alali, W.Q.; Gibson, K.E.; Ricke, S.C.; Crandall, P.; Jaroni, D.; Berrang, M. Salmonella and Campylobacter prevalence and concentration on pasture-raised broilers processed on-farm, in a Mobile Processing Unit, and at small USDA-inspected facilities. Food Control. 2013, 34, 177-182. [CrossRef]

67. Zhao, W.; Leeftink, R.B.; Rotter, V.S. Evaluation of the economic feasibility for the recycling of construction and demolition waste in China-The case of Chongqing. Resour. Conservat. Recycl. 2010, 54, 377-389. [CrossRef]

68. Zeng, X.; Song, Q.; Li, J.; Yuan, W.; Duan, H.; Liu, L. Solving e-waste problem using an integrated mobile recycling plant. J. Clean. Prod. 2015, 90, 55-59. [CrossRef]

69. Oakland, J.S. Statistical Process Control, 5th ed.; Routledge: New York, NY, USA, 2007.

70. Henriksen, E.K. Jig and Fixture Design Manual; Industrial Press Inc.: New York, NY, USA, 1973.

71. Winchester, S. Exactly: How Precision Engineers Created the Modern World; HarperCollins: Glasgow, UK, 2018. 
72. Anderson, D.M. Design for Manufacturability \& Concurrent Engineering: How to Design for Low Cost, Design in High Quality, Design for Lean Manufacture, and Design Quickly for Fast Production; CIM Press: Cambria, CA, USA, 2004.

73. Puvanasvaran, A.P.; Jamibollah, N.; Norazlin, N. Integration of poka yoke into process failure mode and effect analysis: A case study. Am. J. Appl. Sci. 2014, 11, 1332. [CrossRef]

74. Hinckley, C.M. Make No Mistake! An Outcome-Based Approach to Mistake-Proofing; Productivity Press: Boca Raton, FL, USA, 2001.

75. Thomson, C.C.; Jakubowski, M. Toward an open source civilization (Innovations case narrative: Open source ecology). Innov. Technol. Govern. Glob. 2012, 7, 53-70. [CrossRef]

76. Chitturi, R. Emotions by design: A consumer perspective. Int. J. Des. 2009, 3, 7-17.

77. Baraldi, E. Strategy in industrial networks: Experiences from IKEA. Calif. Manag. Rev. 2008, 50, 99-126. [CrossRef]

78. Meyer, T. Selection criteria: Assessing relevant trends and indicators. In Global Production. A Handbook for Strategy and Implementation; Abele, E., Meyer, T., Näher, U., Strube, G., Sykes, R., Eds.; Springer: Heidelberg/Berlin, Germany, 2008; pp. 34-101.

79. Woodcock, J. Home truths on DIY then and now. Yorkshire Post Magazine, 6 May 2006.

80. Brolin, A.; Thorvald, P.; Case, K. Experimental study of cognitive aspects affecting human performance in manual assembly. Prod. Manuf. Res. 2017, 5, 141-163. [CrossRef]

81. Fenik, Y.; Celebi, N.; Wagner, R.; Nikendei, C.; Lund, F.; Zipfel, S.; Riessen, R.; Weyrich, P. Prepackaged central line kits reduce procedural mistakes during central line insertion: A randomized controlled prospective trial. BMC Med. Educ. 2013, 13, 60. [CrossRef] [PubMed]

82. Felipe, J.; Kumar, U.; Abdon, A.; Bacate, M. Product complexity and economic development. Struct. Chang. Econ. Dyn. 2012, 23, 36-68. [CrossRef]

83. Pugh, S. Total Design: Integrated Methods for Successful Product Engineering; Addison Wesley Longman Limited: Harlow, UK, 1991.

84. Moir, W.H.; Mowrer, H.T. Unsustainability. For. Ecol. Manag. 1995, 73, 239-248. [CrossRef]

85. Stegen, K.S. Heavy rare earths, permanent magnets, and renewable energies: An imminent crisis. Energy Policy 2015, 79, 1-8. [CrossRef]

86. Hoekstra, A.Y. The sustainability of a single activity, production process or product. Ecol. Indic. 2015, 57, 82-84. [CrossRef]

87. Hoekstra, A.Y.; Wiedmann, T.O. Humanity's unsustainable environmental footprint. Science 2014, 344, 1114-1117. [CrossRef]

88. Amirapu, A.; Subramania, A. Manufacturing Futures: For India, Reversing the process of de-industrialisation will be hard. Business Standard, 9 May 2014.

89. Rodrik, D. The past, present, and future of economic growth. In Towards a Better Global Economy: Policy Implications for Citizens Worldwide in the 21st Century; Allen, F., Behrman, J.R., Birdsall, N., Fardoust, S., Rodrik, D., Steer, A., Subramanian, A., Eds.; Oxford University Press: Oxford, UK, 2014.

90. Rodrik, D. Unconditional convergence in manufacturing. Q. J. Econ. 2013, 128, 165-204. [CrossRef]

91. Timmer, M.P. (Ed.) The World Input-Output Database (WIOD): Contents, Sources and Methods. WIOD Working Paper Number 10. 2012. Available online: http://www.wiod.org/publications/source_docs/WIOD_ sources.pdf (accessed on 7 September 2019).

92. Dasgupta, S.; Singh, A. Manufacturing, Services and Premature Deindustrialization in Developing Countries: A Kaldorian Analysis. United Nations University Research Paper 2006/49; UNU-WIDER: Helsinki, Finland, 2006.

93. Desilver, D. Most Americans Unaware that as U.S. Manufacturing Jobs Have Disappeared, Output Has Grown. Pew Research Center, 25 July 2017.

94. Hammami, R.; Frein, Y.; Hadj-Alouane, A.B. Supply chain design in the delocalization context: Relevant features and new modeling tendencies. Int. J. Prod. Econ. 2008, 113, 641-656. [CrossRef]

95. Berg, A.; Saskia Hedrich, S.; Lange, T.; Magnus, K.-H.; Mathews, B. The Apparel Sourcing Caravan's Next Stop: Digitization; McKinsey \& Company: New York, NY, USA, 2017.

96. Oqubay, A. Made in Africa: Industrial Policy in Ethiopia; Oxford University Press: Oxford, UK, 2015.

97. Pilling, D. Chinese Investment in Africa: Beijing's Testing Ground. Financial Time, 13 June 2017. 
98. Ayentimi, D.T.; Burgess, J. Is the fourth industrial revolution relevant to sub-Sahara Africa? Technol. Anal. Strateg. 2018, 1-12. [CrossRef]

99. Frey, C.B. Cheap Automation Raises Risk of Premature Deindustrialisation. Financial Times, 30 September 2015.

100. Millington, K.A. How Changes in Technology and Automation Will Affect the Labour Market in Africa; Report 041; Institute of Development Studies: Brighton, UK, 2017.

101. WCED. World Commission on Environment and Development. Our Common Future; Oxford University Press: Oxford, UK, 1987.

102. Bazilian, M.; Rogner, H.; Howells, M.; Hermann, S.; Arent, D.; Gielen, D.; Yumkella, K.K. Considering the energy, water and food nexus: Towards an integrated modelling approach. Energy Policy 2011, 39, 7896-7906. [CrossRef]

103. Hoff, H.; Iceland, C.; Kuylenstierna, J.; te Velde, D.W. Managing the water-land-energy nexus for sustainable development. UN Chronicle 2012, 49, 4. [CrossRef]

104. McCornick, P.G.; Awulachew, S.B.; Abebe, M. Water-food-energy-environment synergies and tradeoffs: Major issues and case studies. Water Policy 2008, 10, 23-36. [CrossRef]

105. Guild, R.L. Infrastructure investment and interregional development: Theory, evidence, and implications for planning. Public Works Manag. Policy 2000, 4, 274-285. [CrossRef]

106. Snieska, V.; Simkunaite, I. Socio-economic impact of infrastructure investments. Econ. Eng. Decis. 2009, 63, 16-25.

107. Srinivasu, B.; Rao, P.S. Infrastructure development and economic growth: Prospects and perspectives. J. Manag. Soc. Sci. Res. 2013, 2, 81-91.

108. Greener, I.; Powell, M. The evolution of choice policies in UK housing, education and health policy. J. Soc. Policy 2009, 38, 63-81. [CrossRef]

109. Smeeding, T.M.; Saunders, P.; Coder, J.; Jenkins, S.; Fritzell, J.; Hagenaars, A.M.; Hauser, R.; Wolfson, M. Poverty, inequality, and family living standards impacts across seven nations: The effect of noncash subsidies for health, education and housing. Rev. Income Wealth 1993, 39, 229-256. [CrossRef]

110. Zhang, X.; Kanbur, R. Spatial inequality in education and healthcare in China. China Econ. Rev. 2005, 16, 189-204. [CrossRef]

111. O'Connor, D.; Ford, J. Increasing the effectiveness of the "Great Green Wall" as an adaptation to the effects of climate change and desertification in the Sahel. Sustainability 2014, 6, 7142-7154. [CrossRef]

112. Shandra, J.M.; London, B.; Williamson, J.B. Environmental degradation, environmental sustainability, and overurbanization in the Developing World: A Quantitative, Cross-National Analysis. Sociol. Perspect. 2003, 46, 309-329. [CrossRef]

113. Agesa, R.U.; Kim, S. Rural to urban migration as a household decision: Evidence from Kenya. Rev. Dev. Econ. 2001, 5, 60-75. [CrossRef]

114. Weeks, J. Population: An Introduction to Concepts and Issues; Thomson Wadsworth: Belmont, CA, USA, 2012.

115. Baird, R.; Migiro, K.; Nutt, D.; Kwatra, A.; Wilson, S.; Melby, J.; Pendleton, A.; Rodgers, M.; Davison, J. Human Tide: The Real Migration Crisis; Christian Aid: London, UK, 2007.

116. Cohen, R.; Deng, F.M. Masses in Flight: The Global Crisis of Internal Displacement; Brookings Institution Press: Washington, DC, USA, 1998.

117. Saha, A.; Hayen, A.; Ali, M.; Rosewell, A.; Clemens, J.D.; MacIntyre, C.R.; Qadri, F. Socioeconomic risk factors for cholera in different transmission settings: An analysis of the data of a cluster randomized trial in Bangladesh. Vaccine 2017, 35, 5043-5049. [CrossRef]

118. Zeledón, R.; Vargas, L.G. The role of dirt floors and of firewood in rural dwellings in the epidemiology of Chagas' disease in Costa Rica. Am. J. Tropic. Med. Hyg. 1984, 33, 232-235. [CrossRef]

119. Smith, A. An Inquiry into the Nature and Causes of the Wealth of Nations; W. Strahan: London, UK, 1776.

120. Ricardo, D. On the Principles of Political Economy and Taxation; John Murray: London, UK, 1817.

121. Porter, M.E. Competitive Advantage: Creating and Sustaining Superior Performance; Free Press: New York, NY, USA, 1985.

122. Phillipson, N. Adam Smith: An. Enlightened Life; Penguin: London, UK, 2010.

123. Giustiniani, V.R. Homo, humanus, and the meanings of 'humanism'. J. Hist. Ideas 1985, 46, 167-195. [CrossRef] 
124. Griswold, C.L. Adam Smith and the Virtues of Enlightenment; Cambridge University Press: Cambridge, UK, 1999.

125. Evensky, J. Adam Smith's Theory of Moral Sentiments: On morals and why they matter to a liberal society of free people and free markets. J. Econ. Perspect. 2005, 19, 109-130. [CrossRef]

126. Morrow, G.R. The Ethical and Economic Theories of Adam Smith: A study in the social philosophy of the 18th century. Cornell Stud. Philos. 1923, 13, 91-107.

127. Smith, A. The Theory of Moral Sentiments; Printed for Andrew Millar, in the Strand; Alexander Kincaid and J. Bell, in Edinburgh: London, UK, 1759.

128. Mead, G.H. Mind, Self, and Society: From the Standpoint of a Social Behaviorist; University of Chicago Press: Chicago, IL, USA, 1934.

129. Thetkathuek, A.; Meepradit, P. Work-related musculoskeletal disorders among workers in an MDF furniture factory in eastern Thailand. Int. J. Occup. Saf. Ergo. 2018, 24, 207-217. [CrossRef]

130. Galbraith, J.K. The Predator State; Free Press: New York, NY, USA, 2008.

131. Irwin, D. Retrospectives: Challenges to free trade. J. Econ. Perspect. 1999, 5, 201-208. [CrossRef]

132. Krugman, P.R. Is free trade passe? J. Econ. Perspect. 1987, 1, 131-144. [CrossRef]

133. Robinson, J. Aspects of Development and Underdevelopment; Cambridge University Press: Cambridge, UK, 1979.

134. Krishnan, A. Make in India Fails to Quench Nation's Dependence on Made in China Goods. India Today, 14 March 2018.

135. Mac, R. Behind the Crash of 3D Robotics, North America's Most Promising Drone Company. Forbes, 5 October 2016.

136. Mukherjee, S. Revisiting the Debate over Import-substituting vs. Export-led Industrialization. Trade Dev. Rev. 2012, 5, 64-76.

137. Bakir, C.; Woods, J. Host state bargaining with multinationals. In Handbook of the International Political Economy of the Corporation; Nölke, A., May, C., Eds.; Edward Elgar Publishing: Cheltenham, UK, 2018; pp. 279-294.

138. Zeuner, B. An obsolescing bargain in a rentier state: Multinationals, artisanal miners, and cobalt in the DRC. Front. Energy Res. 2018, 6, 123. [CrossRef]

139. Addison, J.; Steele, R. The Spectator: With Notes and General Index, from the London Stereotype Edition; Arkose Press: Wahroonga, Australia, 2015.

140. Venables, A.J. Using Natural Resources for Development: Why Has It Proven So Difficult? J. Econ. Perspect. 2016, 30, 161-184. [CrossRef]

141. Brunnschweiler, C.N.; Bulte, E.H. Linking Natural Resources to Slow Growth and More Conflict. Science 2008, 320, 616-617. [CrossRef] [PubMed]

142. Global Financial Integrity. Financial Flows and Tax Havens Combining to Limit the Lives of Billions of People; Global Financial Integrity: Washington, DC, USA, 2015.

143. Lyon, T.P.; Montgomery, A.W. The means and end of greenwash. Org. Environ. 2015, 28, 223-249. [CrossRef]

144. Gazheli, A.; van den Bergh, J.; Antal, M. How realistic is green growth? Sectoral-level carbon intensity versus productivity. J. Clean. Prod. 2016, 129, 449-467. [CrossRef]

145. Mayer, T.; Mucchielli, J.-L. Agglomeration effects, state policies, and competition in the location of Japanese FDI in Europe. In Multinational Location Strategy; Rugman, A.M., Mucchielli, J.-L., Eds.; Emerald Group Publishing Limited: Bingley, UK, 1998; pp. 87-116.

146. Paquette, D. Trump Is Celebrating the Foxconn Deal. the People Paying for It Aren't so Sure. The Washington Post, 14 August 2017.

147. Desai, A. Of Faustian Pacts and mega-projects: The politics and economics of the port expansion in the south basin of Durban, South Africa. Capital. Nat. Social. 2015, 26, 18-34. [CrossRef]

148. Gomes-Casseres, B. Competitive advantage in alliance constellations. Strat. Org. 2003, 1, 327-335. [CrossRef]

149. Koschmann, M.A.; Kuhn, T.R.; Pfarrer, M.D. A communicative framework of value in cross-sector partnerships. Acad. Manag. Rev. 2012, 37, 332-354. [CrossRef]

150. Austin, J.E. Strategic collaboration between nonprofits and businesses. Nonprofit Volunt. Sec. Q. 2000, 29, 69-97. [CrossRef]

151. Fox, S.; Kauttio, J.; Mubarak, Y.; Niemisto, H. Determinants in competition between cross-sector alliances. Adm. Sci. 2017, 7, 31. [CrossRef] 
152. Woodward, D. Incrementum Ad Absurdum: Global Growth, Inequality and Poverty Eradication in a Carbon-Constrained World. World Econ. Rev. 2015, 4, 43-62.

153. Dhahri, S.; Omri, A. Entrepreneurship contribution to the three pillars of sustainable development: What does the evidence really say? World Dev. 2018, 106, 64-77. [CrossRef]

(C) 2019 by the author. Licensee MDPI, Basel, Switzerland. This article is an open access article distributed under the terms and conditions of the Creative Commons Attribution (CC BY) license (http://creativecommons.org/licenses/by/4.0/). 